\title{
Dolichopodidae (Diptera) new for the fauna of Finland
}

\author{
Jere Kahanpää \& Igor Grichanov
}

Kahanpää, J. \& Grichanov, I. 2006: Dolichopodidae (Diptera) new for the fauna of Finland. - Entomol. Fennica 17: 73-78.

Examination of Dolichopodidae deposited in Finnish museum collections in Helsinki, Oulu and Turku, as well as in private collections, yielded 28 species new to Finland. The significance of the new records is discussed. New figures of male genitalia of Chrysotus gramineus (Fallén, 1823) and C. angulicornis Kowarz, 1984 are presented.

Jere Kahanpää, Finnish Environment Institute, P.O. Box 140, FI-00251 Helsinki, Finland (E-mail: kahanpaa@iki.fi).

Igor Grichanov, All-Russian Institute of Plant Protection, Podbelskogo 3, St. Petersburg, Pushkin, 196608 Russia (E-mail: grichanov@mail.ru).

Received 12 February 2004, accepted 3 September 2004

\section{Introduction}

Long-legged flies (family Dolichopodidae) are delicate, small to medium-sized, usually greenish flies. The Dolichopodidae fauna of the world is very species rich, with approximately 6,600 described species in 220 genera (Grichanov 2003). These flies are distributed throughout the world from arctic islands to the tropics, where the species diversity is highest. The adults and larvae of almost all Finnish species are predators inhabiting various humid habitats.

The Finnish dolichopodid fauna was studied with varying intensity during the first half of the $20^{\text {th }}$ century, mainly by R. Frey, R. Stora and E. Thuneberg. After 1960 the interest in this insect group waned and most of the material collected by Finnish entomologists was left unidentified. The existing faunistic knowledge was summarized by W. Hackman (1980) in his check-list of Finnish Diptera. A number of species were erroneously included in the Finnish fauna by Negrobov (1991) in the Palaearctic catalogue of Diptera which was based on a species list from the "Diptera Fennica" part of the Zoological Mu- seum, Finnish Museum of Natural History (FMNH) collection (Negrobov pers. comm.). The collection was created nearly 100 years ago as a depository of material from Finland and the eastern parts of Karelia and the Murmansk Region. We assume Negrobov did not check geographical labels while listing species and as a result, some specimens originating from Russia were listed from Finland.

The Finnish material of Dolichopodidae in main Finnish insect collections has been revised by the authors. During this investigation 28 dolichopodid species proved to be new for Finland. This paper presents the new records in detail.

\section{Material and methods}

The identification of at least one Finnish specimen of each species previously reported from Finland was checked by the senior author in March 2003. During the same year the dolichopodids in the "Diptera Fennica" collection of FMNH, including about 5,000 previously identi- 
fied and 5,000 unsorted specimens from Finland, Russian Karelia and Murmansk Region, were studied by the junior author. Dolichopodids in the Zoological Museum of the Universities of Turku and Oulu, and in the insect collection of the Department of Applied Biology, University of Helsinki (DABUH) were examined by the senior author. New samples of over 6,000 dolichopodid specimens were collected and identified during the years 2002 and 2003.

The structure of the records presented below is: Number of males, number of females, code for biogeographical province: municipality, location (coordinates), date, collector. The provincial codes are documented in Heikinheimo \& Raatikainen (1971) and numerous other papers on the Finnish fauna. Coordinates are given in the Finnish national grid coordinate system.

\section{Results}

The identified material includes 28 species new for Finland. Some of these have previously been listed as Finnish due to misidentification (Sciapus lobipes Meigen, 1824) or frontier adjustments between Russia and Finland after the Second World War (Diaphorus hoffmannseggi Meigen, 1830, Sciapus lobipes, S. albifrons Meigen, 1830). The species accounts are listed in alphabetical order.

\section{Achalcus vaillanti Brunhues, 1987}

Material examined. $6 \hat{\sigma} \delta^{\lambda}, 8$ 우, Om: Pietarsaari (705:325), 26.VI--10.VII.1954, 2.VII2.VIII.1955, 13.VII.1957 and 23.VI.1959, R. Storå; 1 , Om: Pietarsaari, R. Storå; 1 , N: Tvärminne, B. Poppius; 1 +, N: Helsinki, J. Sahlberg; 1 , , Bothnia, J. Sahlberg; 1 \&, N: Helsinki, 6.VIII-21.IX., W. Hellén (in FMNH); 148 exx, N: Helsinki, Kallahdenniemi (667620: 339743), 14.VII.-12.VIII.2003, J. Kahanpää.

Remarks. In Finland $A$. vaillanti seems to be more common than Achalcus flavicollis (Meigen, 1824) - only four females of $A$. flavicollis were found in the material. In Kallahdenniemi numerous specimens were collected from a dense reed bed with a single Malaise trap. Intensive sweepnetting among and along the reed bed yielded no material. The Palaearctic Achalcus species have been revised by Pollet (1996).
Argyra ilonae Gosseries, 1989

Material examined. 12 ふึ่ํㅇ, Ab: Vihti, 1945, R. Frey; 1 ô, Ab: Lohja, Vaanila, 24.VII. 1941, R. Frey; 1 ग, Sa: Joutseno, 18.VI.1960, E. Thuneberg; 6 §ð, N: Sipoo, Nevas (6687:3418),

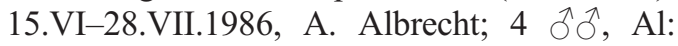
Jomala, H. Krogerus; 1 ते, Al: Maarianhamina, 6.VII.1946, W. Hellén (in FMNH).

Remarks. Misidentified as Argyra diaphana (Fabricius, 1775) or A. leucocephala (Meigen, 1824).

\section{Argyra setimana Loew, 1859}

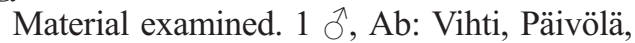
16.VI.1946, R. Frey; 1 $\hat{\jmath}$, Ab: Vihti, 10.VII. 1945, R. Frey; 1 ô, Sb: Kuopio, Rautalahti, 26.VI.1949, W. Hellén; 1 đ̃, Myllyoja, 31.VII. 1964, L. Tiensuu (in FMNH).

Remarks. The second specimen from Vihti was misidentified by R. Frey as $A$. subarctica Ringdahl, 1920, which was then erroneously listed as Finnish by Frey (1948), Hackman (1980) and Negrobov (1991).

\section{Chrysotimus molliculus (Fallén, 1823)}

Material examined. 1 q, Sa: Ristiina (6826:3502), 24.VII.1977, M. Koponen (in DABUH); 1 q, N: Helsinki, Vantaanjoki (6679: 3388), 8.IX.2002, J. Kahanpää.

Remarks. In Helsinki swept from bushes growing on a forest edge near the Vanhankaupunginlahti reserve, a large reed marsh and wetland area. Erroneously recorded from Finland by Stackelberg (1962).

\section{Chrysotus angulicornis Kowarz, 1874}

Material examined. 1 ô, N: Hanko, Henriksberg, 8.VII.1932, R. Frey; 1 § Ab: Vihti, Päivölä, 27.VI.1944, R. Frey (in FMNH).

Remarks. The species was erroneously listed as a synonym of $C$. gramineus (Fallén, 1823) in the Swedish list (Grichanov 2002a). Despite the very similar habitus of the two species, they can be separated by the shape of the aedeagus (Fig. 1) and the subtriangular postpedicel of $C$. angulicornis. The male genitalia figure for $C$. angulicornis in Buchmann (1961) do very probably belong to C. gramineus. 
a
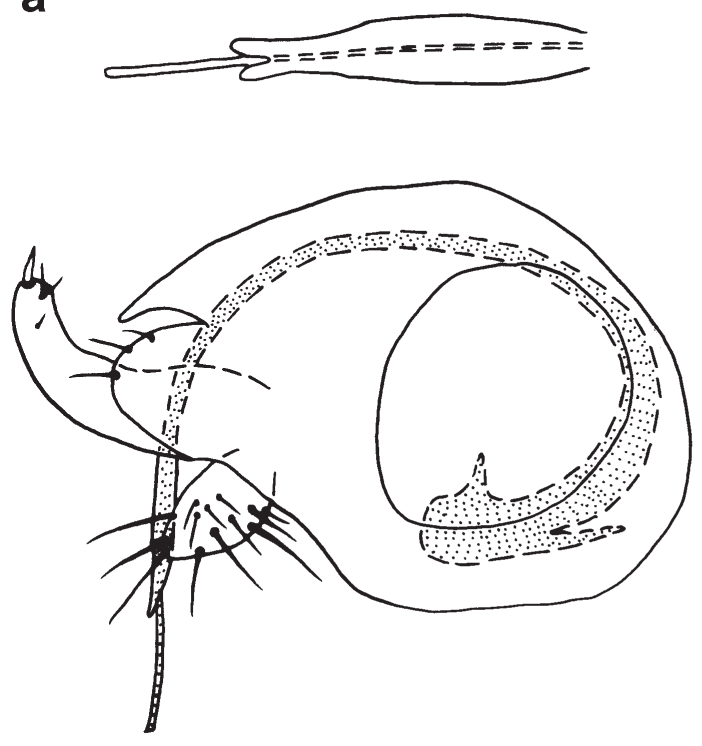
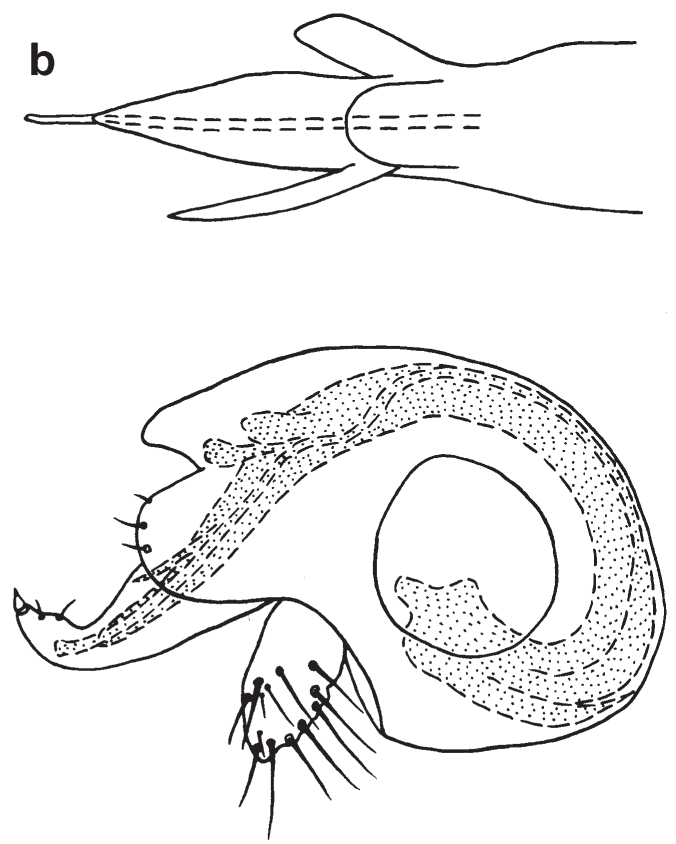

Fig. 1. Aedeageus and hypopygium of -a. Chrysotus angulicornis Kowarz and - b. Chrysotus gramineus (FII.)

Diaphorus hoffmannseggi Meigen, 1830

Material examined. 1 ๙ , Ab: Lohja, 20.VII. 1947, W. Hellén (in FMNH).

Remarks. Previously recorded as Finnish from Isthmus Carelia, now a part of Leningrad Region, Russia (Frey, 1915).

Dolichopus albifrons Loew, 1859

Material examined. $1 \hat{\partial}$, Ab: Korppoo, Jurmo, 8.VIII.1960, M. Meinander (FMNH).

\section{Dolichopus apicalis Zetterstedt, 1849}

Material examined. 1 ऽ̊, Sa: Joutseno, 1.VII. 1945, L. Tiensuu (FMNH); 1 ふै, N: Helsinki, Kallahdenniemi (6676:3397), 21.VII. 2003, J.

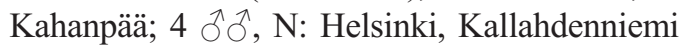
(667620:339743), 14.-25.VII. 2003, J. Kahanpää.

Remarks. Erroneously mentioned by $\mathrm{Ne}$ grobov (1991) from Finland instead of Sweden.

Dolichopus calinotus Loew, 1871

Material examined. $1 \hat{\partial}$, N: Helsinki, Kallahdenniemi (667620:339743), 25.VII.5.VIII.2003, J. Kahanpää.
Dolichopus cinctipes Wahlberg, 1850

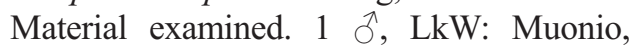
Ylikylä, 5.VII.1911, R. Frey.

Dolichopus clavipes Haliday, 1832

Material examined. 1 o, St: Eura, 16.VII. 1957, R. Storå.

Dolichopus latilimbatus Macquart, 1827

Material examined. 1 $\lesssim, \mathrm{N}$ : Helsinki, Kallahdenniemi (667620:339743), 14.-25.VII. 2003, J. Kahanpää.

Dolichopus signifer Haliday, 1838

Material examined. 1 +, Ab: Korppoo, Jurmo, 8.VIII.1960, M. Meinander.

Dolichopus subpennatus d'Assis Fonseca, 1976

Material examined. 1 ô, N: Helsinki, Santahamina, 14.VI.1919, A. Ulvinen; 1 đ, Ta: Orivesi, 29.VI.1946, L. Tiensuu; 1 đ̊, Sa: Imatra, 811.VI.1956, H. Lindberg; 1 ई̊, Ab: Karjalohja, Torhola, 26.VI.1934, R. Frey; 1 ô, Ab: Karjalohja, 3.VII.1933, Krogerus; 1 ô, Ab: Vihti, Päivölä, 16.VI.43, R. Frey; 1 ふૈ, N: Porvoo, 1932-34, P. Suomalainen.

Remarks. D. subpennatus, described origi- 
nally from England and mentioned for Russia, is an obviously overlooked species and appears to be widely distributed in Europe.

Lamprochromus strobli Parent, 1925

Material examined. 1 ๙ , Sb: Nilsiä, 27.VI. 1865, E. Palmén (in FMNH); 1 ○ 1 ㅇ, N: Helsinki, Kallahdenniemi (667620:339743), 1.8.VII.2003 and 3 ふึ 1 ๆ 25.VII.-5.VIII.2003, J. Kahanpää; 1 +, Ka: Hamina, Salmi (6716:3500), 22.VII.2003, J. Kahanpää.

Remarks. All new Finnish specimens have been collected from reed beds.

\section{Medetera micacea Loew, 1857}

Material examined. $1 \hat{\jmath}, \mathrm{N}$ : Helsinki, 16.VI.31.VII.1915, W. Hellén; 1 †, Ta: Valkeala, R. Frey (in FMNH).

\section{Rhaphium albifrons Zetterstedt, 1843}

Material examined. 2 ऽึ 2 우, Le: Kilpisjärvi, Saana (767:325), 29.VII.2003, J. Kahanpää (1 0 in FMNH).

Remarks. Swept from low emergent vegetation growing along mountain streams at places where the stream slows down and spreads to form a seepage area. Found only near the upper edge of the subalpine birch forest; extensive searching in the lower alpine region and the main subalpine forest proved unsuccessful. The specimens examined have the legs mainly brown instead of mainly yellow as described by Negrobov (1979).

\section{Rhaphium auctum Loew, 1857}

Material examined. 1 o, Om: Pietarsaari, Varvet, 21.VII.1957, R. Frey; 1 o, Al: Jomala (668:310), 12.VI.1956, R. Storå (in FMNH).

\section{Sciapus albifrons (Meigen, 1830)}

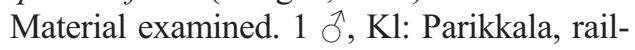
way station, 28.VII.1945, W. Hellén (in FMNH).

Remarks. Previously recorded as Finnish from Isthmus Carelia, now a part of Leningrad Region, Russia (Frey 1927).

Sciapus basilicus Meuffels \& Grootaert, 1990

Material examined. $1 \hat{\sigma}$, N: Tvärminne, year 1923, A. Wegelius (in FMNH).

Remarks. The European species of the Sciapus contristans (Wiedemann, 1817) species group have been revised by Meuffels \& Grootaert (1990). In earlier literature the name contristans was used for several species. In Finland this name has been used for Sciapus basilicus, S. zonatulus (Zetterstedt, 1843) and also S. wiedemanni (Fallén, 1823).

\section{Sciapus lobipes (Meigen, 1824)}

Material examined. 1 o, Li: Inari (7617: 3521), 6.VII.1989, M. Koponen (in DABUH).

Remarks. Previously recorded as Finnish from Isthmus Carelia, now a part of Leningrad Region, Russia (Frey 1927). Erroneously recorded from Finland by Negrobov (1991). A female from Le: Enontekiö (7609:3348) in the insect collection of University of Turku does probably also belong to this species. These northern records and the absence of find in southern Finland or Sweden is curious; the general distribution pattern of $S$. lobipes is by no means limited to boreal or montane regions.

\section{Sciapus zonatulus (Zetterstedt, 1843)}

Material examined. 1 đ, N: Lappohja, 13.VII. 1920, R. Frey; 1 ふૈ, N: Tvärminne, Zoological Station, 28.VI.1925, R. Frey; 1 ô, N: Porvoo, P. Suomalainen (in FMNH).

\section{Syntormon aulicus (Meigen, 1824)}

Material examined. 4 우, Ab: Karjalohja, 26.VII-9.VIII.1911, W. Hellén; 2 우, N: Espoo, 10.-17.VII.1910, W. Hellén (in FMNH).

\section{Systenus scholtzii (Loew, 1850)}

Material examined. 1 đ̂, Al: Lemland, Nåtö (668:310), 3.VI.2002, D. Rotheray.

Remarks. Found in a rothole in the trunk of a living birch.

\section{Tachytrechus hamatus Loew, 1871}

Material examined. 1 $\widehat{\partial}$, Ta: Hattula, Parola (67743:33571), 15.VI.2003, J. Kahanpää.

Remarks. Found among old Typha on the edge of a boglet. Among north European species T. hamatus could be confused with T. ammobates (Haliday in Walker, 1851), but features entirely yellow scape and pedicel, an entirely black hind basitarsus, and black cerci with long apical hairs. Females have a yellow-brown face and predominantly dark fore tibia. 


\section{Telmaturgus tumidulus (Raddatz, 1873)}

Material examined. 1 , N: Kirkkonummi, Evitskog, 23.VI.1954, W. Hackman (FMNH); 1 đ, Ta: Hattula, Parola (67743:33571), 15.VI. 2003, J. Kahanpää.

Remarks. In Hattula found together with Tachytrechus hamatus Loew, 1871 (see above) on leaves of Typha. Erroneously reported from Finland by Stackelberg (1962).

\section{Thrypticus intercedens Negrobov, 1967}

Material examined. 1 ते, Sa: Joutseno, Patakahja, 23.VI.1956 E. Thuneberg; 1 त, Al: Saltvik, Kvarbo, 10.VII.1942, R. Frey; 1 đે, N: Tvärminne, 10.VII.1919, R. Frey; $4 \hat{\jmath} \widehat{\partial}, \mathrm{Ab}$ : Parainen, R. Frey; 1 त, Om: Pietarsaari, Varvet,

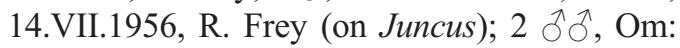
Pietarsaari, Varvet, 22.VII.1957, R. Frey; 1 ๙,

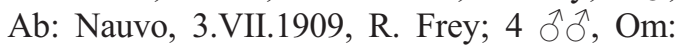
Luoto, 8.VII. \& 13.VII.1954, R. Storå; 1 ô, Ab: Karjalohja, H. Krogerus; 1 ô, N: Porvoo, 193234, P. Suomalainen; 1 गे, Om: Uusikaarlepyy, 20.VII.1955. R. Storå; 1 ô, Om, Jakobstad,

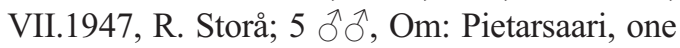
label with date 23.VII.1955, R. Storå; 1 ô, Om: Pietarsaari, 9.VII. \& 10.VII.1954, R. Storå; 2 ô, Om: Pietarsaari (705:325), 9.VII. \& 23.VII.1957, R. Storå (in FMNH). Ka: Hamina, Pitkäthiekat (6712:3513), 22.VII.2003, J. Kahanpää; N: Helsinki, Kallahdenniemi (6676:3397), 8.VII.2003, J. Kahanpää.

Remarks. Thrypticus intercedens is very close to T. pollinosus Verrall, 1912, differing in distal thin part of hypandrium being as long as or longer (rather than $1 / 3$ shorter in $T$. pollinosus) than proximal broad part (Negrobov \& Stackelberg 1972). This character is usually clearly visible in dry specimens.

\section{Thrypticus nigricauda Wood, 1913}

Material examined. $1 \hat{\jmath}$, Ab: Karjalohja, Pellonkylä, 11.VIII.1928, R. Frey (in FMNH).

Remarks. Misidentified as Thrypticus bellus Loew, 1869 by Frey.

\section{Discussion}

How complete is our knowledge of the Dolichopodidae fauna of Finland? The number of species known from Sweden is 323 (Grichanov 2002a, 2004), i.e., substantially larger than the 237 species currently known from Finland (Kahanpää \& Grichanov 2004). Some reasons for this difference are easily found. Many halotopophilous species are known only from the southwestern coast of Sweden and they are unlikely to be found in Finland. The genus Hercostomus, abundant in temperate and warm zones, is very poorly represented in Finland. The numbers of mature and old-growth forest species, especially Medetera, are almost equal.

As expected, the southern part of Finland has been studied much more intensively than the forest and bog areas in the north. Comparison with the checklists for Sweden (Grichanov 2002a), Estonia (Grichanov 2002b) and Russian Karelia (Grichanov \& Polevoi 2004) reveal that many northern species are still lacking in the checklist, but are probably present in this country. We estimate that at least another 30 species are still to be found in Finland.

Most of the species listed in this paper have been found in southern Finland and belong to the well-known central and western European fauna. Only Dolichopus cinctipes and Rhaphium albifrons break this pattern; the first species is found in Sweden and all of northernmost Russian from the Kola peninsula to Maritime Territory, while $R$. albifrons lives on mountain ranges in Fennoscandia, France, Switzerland, Romania, Romania, Afganistan and Russia (Negrobov 1991).

Among the southern species, two groups of species call for special attention. The first includes species collected from reed beds ( $A$. vaillanti, D. apicalis, D. calinotus, D. latilimbatus, $T$. intercedens, $T$. nigricauda and $L$. strobli). This habitat has clearly been neglected by Finnish investigators of Dolichopodidae. The other group includes coastal species probably limited to the south-western archipelago in Finland. There are practically no old records from the smaller islets, and during a brief visit to Jurmo in 1960 M. Meinander found two species (Dolichopus albifrons \& signifer) new for Finland. Detailed studies of such habitats in any part of Fin- 
land will most probably result in several new records.

Acknowledgements. The work in the FMNH has been supported by the Finnish Academy of Sciences grant 203683. We would like to thank Dr. Pekka Vilkamaa (FMNH) and Dr. Matti Viitasaari (DABUH) for the opportunity to study the collections in their care. We express sincere gratitude to Dr. Hans Silfverberg for his help in reading old labels, and to Dr. Graham Rotheray for permission to publish his record of Systenus scholtzii in this paper.

\section{References}

Buchmann, W. 1961: Die Genitalanhänge mitteleuropäischer Dolichopodiden. - Zoologica (Stuttgart), 39(5): 1-51 + $13 \mathrm{pl}$.

Frey, R. 1915: Zur Kenntnis der Dipterafauna Finlands. III. Dolichopodidae. - Acta Soc. F. Fl. Fenn. 40(5): 179.

Frey, R. 1927: Kokoustiedonantoja. — Notulae Ent. 7: 60.

Frey, R. 1948: Nykomlingar för Finlands dipterfauna. Notulae Ent. 28: 126-127.

Grichanov, I. Ya. 2002a: A check list of Swedish Dolichopodidae (Diptera). — Entomol. Tidskr. 123(2): 119-130.

Grichanov, I. Ya. 2002b: A check list of Estonian Dolichopodidae (Diptera). — Int. J. Dipter. Res., V. 13(2): 127-133.

Grichanov I. Ya. 2003: A check list of species of the family Dolichopodidae (Diptera) of the World arranged by alphabetic list of generic names. [www document]. URL http://www.fortunecity.com/greenfield/porton/875/Genera3.htm.

Grichanov, I. Ya. 2004: A list of Dolichopodidae from the Tyresta National Park, Sweden, with description of a new species of the genus Rhaphium Meigen (Diptera). - Zoosystematica Rossica, 12(2/2003): 267-269.

Grichanov, I. Ya. \& Polevoi, A. V. 2004: Dolichopodidae of Russian Karelia. - Zoosystematica Rossica, 12(2/2003): 271-275.

Hackman, W. 1980: A check list of the Finnish Diptera I. Nematocera and Brachycera (s. str.). - Notulae Ent. 60: 19-48.

Heikinheimo, O. \& Raatikainen, M. 1971: The recording of localities of biological finds in Finland. - Ann. Ent. Fenn. 37(1a): 9-27.

Kahanpää, J. \& Grichanov, I. Ya. 2004: A check-list of Finnish long-legged flies (Diptera:Dolichopodidae). — Int. J. Dipterol. Res. 15(1): 57-62.

Meuffels, H. J. G. \& Grootaert, P. 1990: The identity of Sciapus contristans (Wiedemann, 1817), and a revision of the species group of its relatives - Bulletin de 1'Institut Royal des Sciences Naturelles de Belgique, Entomologie 60:161-178.

Negrobov, O. P. 1979: Dolichopodidae, Unterfamilie Rhaphiinae - In: Lindner, E. (ed.), Die Fliegen der Palaearktischen Region, Band IV: 475-530. E. Schweizerbart'sche Verlagsbuchhandlung, Stuttgart.

Negrobov, O. P. 1991: Dolichopodidae. - In: Soos A., Papp L. \& Oosterbroeck P. (eds.), Catalogue of Palaearctic Diptera 7: Dolichopodidae-Platypezidae: 11139. Akademiai Kiado, Budapest. 291 pp.

Negrobov, O. P. \& Stackelberg, A. A. von 1972: Dolichopodidae, Unterfamilie Medeterinae. - In: Lindner, E. (ed.). Die Fliegen der Palaearktischen Region. Band IV(289): 257-302. E. Schweizerbart'sche Verlagsbuchhandlung, Stuttgart.

Pollet, M. 1996: Systematic revision and phylogeny of the Palaearctic species of the genus Achalcus Loew (Dipter:Dolichopodidae) with the description of four new species. - Systematic Entomology 21: 353-386.

Remm H. \& Elberg K. 1970: Diptera (pp. 195-197). — In: Puhtu laiu selgrootud, Aktiklite kogumik "LääneEesti rannikualade loodus": 164-200. Valgus, Tallinn.

Stackelberg A. A. von 1962: Materials on the Diptera fauna of the Leningrad Region. V. Dolichopodidae In: Trudy Zool. Inst. Akad. Nauk SSSR, 31 (Fauna of the Leningrad Region and Karelia): 280-317. Akad. Nauk SSSR, Moscow \& Leningrad. 